\title{
HUBUNGAN ANTARA KUALITAS PRODUK DAN KUALITAS LAYANAN DENGAN KEPUASAN PELANGGAN PADA PERUSAHAAN DAGANG ADZA CATERING KOTA BOGOR
}

\author{
Nia Sonani ${ }^{1)}$, Hari Muharam ${ }^{21}$, dan Ferdisar Adrian ${ }^{2)}$ \\ ${ }^{1)}$ Dosen Universitas Nusa Bangsa \\ 2) Dosen Pascasarjana Universitas Pakuan \\ E-mail: nia_ekonomi@yahoo.co.id
}

\begin{abstract}
This research is included as a correlational research, and consisted of two independent variables and one dependent variable, i.e. product quality and service quality with customer satisfaction. The research was conducted on customer of Adza Catering, with samples of 100 customers, derived by random sampling. The method used was survey and data analysis technique using statistical test of correlation and linear regression. The hypothesis testing was conducted at the significant level of $\alpha=0.05$. The results yield three conclusions, namely: first, there is a highly significant positive relationship between product quality and customer satisfaction with a correlation coefficient $r_{y 1}$ of 0.647 , coefficient of determination of 0.4186 and the regression equation is $\hat{Y}=56.220+0.419 X_{1}$. Second, there is a highly significant positive relationship between service quality and customer satisfaction with correlation coefficient $r_{y 2}$ of 0.763 , coefficient of determination of 0.5821 and the regression equation is $\hat{Y}=40.773+0.376 X_{2}$. Third, there is a highly significant positive relationship between product quality and service quality together simultaneously with customer satisfaction with a correlation coefficient $R_{y .1 .2}$ of 0.740 , coefficient of determination of 0.5476 and the regression equation is $\hat{Y}=22.612+0.428 X_{1}+0,236 X_{2}$. Based on these results, it can be concluded that product quality and service quality provide highly significant contribution to customer satisfaction.
\end{abstract}

Keywords: Product Quality, Service Quality and Customer Satisfaction

\section{PENDAHULUAN}

Kebutuhan dalam pemenuhan hidup semakin berkembang, bukan hanya dari segi kebutuhan ilmu pengetahuan dan teknologi namun juga kebutuhan akan kepuasan dari jasa yang diberikan. Perkembangan tersebut tentunya menjadi sebuah kesempatan atau chance guna menyerap tenaga kerja yang lebih banyak untuk pemenuhan kebutuhan akan kepuasan konsumen. Hal ini menjadi tantangan bagi perusahaan untuk mempertahankan posisi pasarnya di tengah persaingan yang semakin ketat sangatlah banyak. Sehingga perusahaan dituntut harus berusaha membuat konsumen merasa puas dengan memberikan penawaran dan pelayanan yang lebih berkualitas.
Seiring dengan pesatnya perkembangan jasa serta peran pentingnya dalam mendukung perekonomian, maka diperlukan suatu upaya pemasaran dan pengelolaan pada jasa secara lebih spesifik dan lebih profesional. Strategi pemasaran untuk perusahaan jasa sangat berbeda dengan strategi pemasaran pada perusahaan manufaktur. Hal ini dikarenakan sifat jasa yang tidak dapat dikenali secara langsung oleh konsumen (intangible) sehingga konsumen dapat menilai jasa dari aspek yang lain, misalnya tingkat harga maupun tingkat pelayanan yang diterima. Padahal, dalam melakukan keputusan pembelian suatu produk (baik barang maupun jasa) pengetahuan konsumen tentang sesuatu yang akan dibelinya sangat berpengaruh.

JIMFE (Jurnal Ilmiah Manajemen Fakultas Ekonomi)

Volume 3 No. 1 Tahun 2017, Hal. 29-39 
Pelayanan jasa yang sering dikonsumsi berdasarkan hal tersebut adalah sektor jasa boga atau usaha catering. Perkembangan pasar industri jasa boga/usaha catering di dalam negeri yang terus berkembang disebabkan oleh perkembangan sektor pengkonsumsinya yang cukup luas, begitu luasnya segmen pasar industri ini menyebabkan jumlah pelaku jasa boga/usaha catering dalam negeri terus berkembang sehingga jumlahnya mencapai ribuan.

Menurut Lovelock dan Wirts (2011:h.60) kepuasan adalah semacam perilaku yang terjadi setelah mengkomsumsi layanan. Pelanggan akan terpuaskan selama yang dirasakan konsumen berada pada tingkat layanan memadai (adequate service level) dan akan sangat senang bila tingkat layanan mendekati atau melebihi yang diinginkan (desired service level). Menurut Lupiyoadi Rambat dan Hamdani (2001:h.127), dimensi kepuasan pelanggan antara lain: 1 ) Kualitas Produk, 2) Harga, 3) Mutu Pelayanan, 4) Emosional, dan 5) Biaya dan Kemudahan.

Menurut Tjiptono (2006:h.51) kualitas produk adalah suatu kondisi dinamis yang berhubungan dengan produk, jasa manusia, proses dan lingkungan yang memenuhi atau melebihi harapan. Menurut Lupiyoadi dan Hamdani (2006:h.175) kualitas produk adalah derajat yang dicapai oleh karakteristik yang berkaitan dalam memenuhi persyaratan. Menurut Lupiyoadi dan Hamdani (2006:h.6873) dimensi tentang produk terdiri: 1) Kinerja, 2) Keandalan, 3) Kesesuaian, 4) Ketahanan/Daya Tahan, 5) Kemampuan Pelayanan, 6) Estetika, dan 7) Kualitas yang dipersepsikan.

Menurut Tai dan Chew (2012.h:38) kualitas layanan adalah sangat sulit ditiru pesaing, karena bukanlah benda nyata. Teknologi dan mesin tidak dapat mengandalkan kualitas layanan, karena layanan biasanya diberikan manusia yang hampir tidak mungkin distandarisasi. Mereka memiliki pemikiran sendiri dan tidak selalu melakukan apa yang diperintahkan. Menurut
Lovelock, Wirtz dan Mussry (2010:h.152) kualitas layanan dari sudut pandang pengguna sebagai sesuatu yang secara konsisten memenuhi atau melampaui harapan pelanggan. Dua faktor utama yang mempengaruhi kualitas jasa yaitu jasa yang diharapkan (expected service) dan jasa yang dipersepsikan (perceived service). Dimana jasa bisa diterima dan dirasakan (perceived service) sesuai yang diharapkan (expected service), maka kualitas jasa dapat dipersepsikan baik dan memuaskan. Apabila jasa yang diterima dapat melebihi harapan pelanggan, maka kualitas jasa tersebut dipersepsikan sebagai kualitas yang ideal. Akan tetapi apabila jasa yang diterima lebih rendah daripada yang diharapkan, maka kualitas jasa sangat tergantung pada kemampuan penyedia jasa menyediakan jasa kepada konsumen secara continue dan konsisten.

Berdasarkan data dalam kurun waktu 3 (tiga) tahun terakhir Adza Catering mengalami penurunan jumlah baik pelanggan korporat maupun individu, hal ini dikarenakan persaingan antar jasa catering di wilayah Bogor dan informasi dari mulut ke mulut yang negatif terhadap kualitas produk dan jasa layanan pada Adza Catering. Meskipun penurunan jumlah pelanggan catering tidak seberapa besar namun tentunya ini menjadi perhatian dari manajemen usaha Adza Catering untuk meningkatkan kualitas produk dan jasa pelayanan terhadap pelanggan.

Secara umum penelitian ini bertujuan untuk memperoleh informasi mengenai keterkaitan antara kualitas produk dan kualitas layanan sebagai variabel bebas dengan kepuasan pelanggan sebagai variabel terikat. Secara khusus penelitian ini bertujuan untuk: 1) Mengetahui hubungan antara kualitas produk dengan kepuasan pelanggan, 2) Mengetahui hubungan antara kualitas layanan dan kepuasan pelanggan, dan 3) Mengetahui hubungan antara kualitas produk 
dan kualitas layanan secara bersama-sama dengan kepuasan pelanggan.

Hasil penelitian ini diharapkan dapat menambah wawasan penulis dalam manajemen serta studi tentang kualitas produk, kualitas layanan dan kepuasan pelanggan juga diharapkan dapat memberikan manfaat diberbagai pihak diantaranya adalah: 1) Hasil penelitian ini dapat menjadi bahan masukan dan bahan kajian bagi perusahaan, dalam hal ini manajemen Adza Catering. Temuan yang didapat diharapkan dapat memberikan kontribusi berupa informasi pendukung yang dapat turut dipertimbangkan dalam pengambilan keputusan dan atau kebijakankebijakan terkait dengan upaya peningkatan kualitas produk. 2) Temuan yang didapat diharapkan dapat memberikan kontribusi berupa informasi pendukung yang dapat turut dipertimbangkan dalam pengambilan keputusan dan atau kebijakan-kebijakan terkait dengan upaya peningkatan kualitas produk. 3) Masukan informasi tambahan bagi manajemen Adza Catering mengenai pentingnya kepuasan pelanggan melalui kualitas produk dan kualitas layanan. 4) Membantu manajemen Adza Catering meningkatkan kepuasan pelanggan khususnya dengan meningkatkan kualitas produk dan kualitas layanan. 5) Memberi informasi bagi manajemen Adza Catering mengenai aspek-aspek kepemimpinan transkualitas produk dan kualitas layanan yang perlu dikelola lebih lanjut dalam rangka upaya peningkatan kepuasan pelanggan.

\section{METODOLOGI PENELITIAN}

Penelitian ini dilakukan di perusahaan dagang Adza Catering Kota Bogor. Perusahaan ini bergerak di bidang jasa boga. Metode yang digunakan adalah metode survey dengan pendekatan korelasional. Perolehan data primer di lapangan menggunakan kuesioner yang disusun berdasarkan indikator-indikator yang ada dalam variabel penelitian.
Populasi dalam penelitian ini adalah pelanggan Adza Catering yang berjumlah 133 orang, dengan jumlah sampel yang menggunakan rumus slovin sebanyak 100 orang. Pengambilan sampel dilakukan secara random sampling. Sedangkan uji coba instrumen diambil 30 orang pelanggan yang merupakan bagian dari populasi di luar sampel penelitian.

Analisis data diawali dengan statistik deskriptif yang memunculkan data-data untuk menghitung rata-rata (mean), nilai tengah (median), nilai paling sering muncul (modus), simpangan baku (standar deviasi), rentang kelas, varian sampel dan membuat histogram. Kemudian dilakukan uji persyaratan analisis terdiri dari uji normalitas dengan Kolmogorov-Smirnov, uji homogenitas varians dengan Levene Test, dan uji linearitas dengan menggunakan uji $F$. Selanjutnya adalah uji hipotesis berupa: 1) Analisis regresi sederhana untuk menguji bagaimana variabel terikat $(\mathrm{Y})$ dapat diprediksi melalui variabel bebas $\left(X_{1}\right.$ dan $\left.X_{2}\right)$. Dengan perhitungan linearitas regresi sederhana menggunakan persamaan $\hat{Y}=a+$ $\mathrm{b}_{1} \mathrm{X}_{1}$ untuk persamaan regresi kualitas produk dan kepuasan pelanggan, dan $\hat{Y}=a+b_{2} X_{2}$ untuk persamaan regresi kualitas layanan dan kepuasan pelanggan. 2) Uji korelasi sederhana yaitu korelasi antara kualitas produk dengan kepuasan pelanggan dan antara kualitas layanan dengan kepuasan pelanggan menggunakan teknik korelasi pearson product moment. 3) Analisis regresi ganda untuk mengetahui hubungan fungsional antara variabel $X_{1}$ dan variabel $X_{2}$ secara bersama-sama dengan variabel $Y$, dengan perhitungan linearitas regresi ganda menggunakan persamaan $\hat{Y}=a+b_{1} X_{1}+b_{2} X_{2}$. 4) Uji korelasi ganda untuk mencari besarnya hubungan dan kontribusi dua variabel bebas $\left(X_{1}\right.$ dan $\left.X_{2}\right)$ secara simultan dengan variabel terikat $(\mathrm{Y})$. 


\section{HASIL PENELITIAN DAN PEMBAHASAN}

Hipotesis pertama yang diajukan adalah terdapat hubungan positif antara kualitas produk dengan kepuasan pelanggan. Bisa dikatakan bahwa semakin baik kualitas produk, maka akan semakin tinggi kepuasan pelanggan, begitu juga sebaliknya jika kualitas produk rendah, maka akan bertambah rendah pula kepuasan pelanggan.

Berdasarkan hasil analisis regresi linear sederhana diperoleh bahwa nilai koefisien regresi $b$ adalah sebesar 0,419 dan nilai konstanta a sebesar 56,220. Dengan demikian persamaan regresi antara variabel kualitas produk dengan kepuasan pelanggan adalah $\hat{Y}=56,220+0,419 X_{1}$.

.Untuk mengetahui apakah model persamaan regresi tersebut dapat digunakan untuk menarik kesimpulan atau apakah persamaan regresi yang telah diperoleh signifikan atau tidak, dapat diketahui dengan menggunakan analisis varians (uji-F). Dan tabel ANOVA tersebut dijelaskan pada Tabel 1.

Tabel 1. Model ANOVA

Untuk Uji F Analisis Regresi $\hat{Y}=56,220+0,419 X_{1}$

ANOVA $^{\mathrm{a}}$

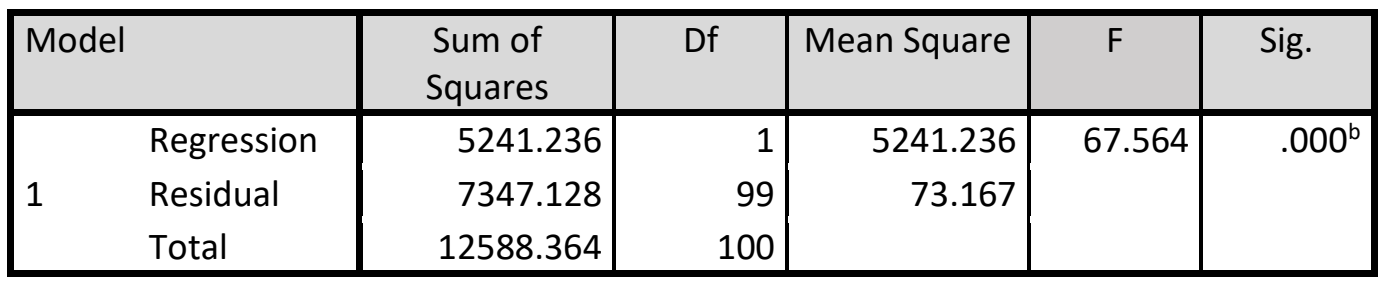

a. Dependent Variable: Kepuasan Pelanggan

b. Predictors: (Constant), Kualitas Produk

Berdasarkan tabel di atas, maka dapat diketahui bahwa persamaan regresi $\hat{Y}=$ $56,220+0,419 X_{1}$ dapat digunakan untuk menjelaskan dan mengambil kesimpulan lebih lanjut mengenai hubungan antara kualitas produk dengan kepuasan pelanggan, karena berdasarkan daftar nilai-nilai distribusi $F$, harga $F$ pada derajat kebebasan (dk) $\mathrm{dk}_{\text {penyebut }}=1 \mathrm{dan} \mathrm{dk}_{\text {pembilang }}=99$ menghasilkan $F_{\text {tabel }}=3,94$. Dari perhitungan uji $F$ tersebut menghasilkan $F_{\text {hitung }}=67,564$. Dengan demikian sesuai kriteria pengujian signifikansi regresi, bahwa $F_{\text {hitung }}$ harus lebih besar dari $F_{\text {tabel }}$ diperoleh hasil perhitungan $67,564>3,94$. Hal ini memberi makna bahwa arah nyata pada taraf kepercayaan $95 \%$ adalah nyata.

Berdasarkan pengujian linearitas regresi diperoleh besarnya data Sig. $=0,014$ (dilihat dari nilai signifikan deviation from linearity yang tercantum pada tabel ANOVA). Syarat pengujian linearitas regresi adalah data Sig < taraf kesalahan 5\% $(\alpha=0,05)$. Dengan demikian karena $0,014<0,05$, maka dapat disimpulkan bahwa regresi linear diterima.

Hasil perhitungan korelasi sederhana pasangan data variabel kualitas produk $\left(\mathrm{X}_{1}\right)$ dengan kepuasan pelanggan ( $(Y)$ menghasilkan nilai koefisien korelasi $r_{x 1 . y}$ sebesar 0,647. Dan dapat dijelaskan pada Tabel 2. 
Tabel 2. Tabel Correlations untuk Data Regresi Hipotesis 1

Correlations

\begin{tabular}{|ll|r|r|}
\hline & \multicolumn{1}{|c|}{$\begin{array}{c}\text { Kualitas } \\
\text { Produk }\end{array}$} & $\begin{array}{c}\text { Kepuasan } \\
\text { Pelanggan }\end{array}$ \\
\hline Kualitas Produk & Pearson Correlation & 1 & $.647^{* *}$ \\
& Sig. (1-tailed) & 100 & .000 \\
& $\mathrm{~N}$ & 100 \\
\hline Kepuasan Pelanggan & Pearson Correlation & $.647^{* *}$ & 1 \\
& Sig. (1-tailed) & .000 & \\
& $\mathrm{~N}$ & 100 & 100 \\
\hline
\end{tabular}

**. Correlation is significant at the 0.05 level (1-tailed).

Angka ini menjelaskan bahwa hubungan kualitas produk $\left(X_{1}\right)$ dengan kepuasan pelanggan $(\mathrm{Y})$ adalah positif dengan tingkat hubungan kuat.

Untuk mengetahui apakah koefisien korelasi $r_{x 1 . y}$ yang diperoleh signifikan atau tidak, dilakukan pengujian dengan menggunakan analisis uji-t. Hasil perhitungan uji- $t$ diperoleh angka sebesar 5,777. Pada uji dua pihak dengan taraf signifikansi $\alpha=0,05$ diperoleh $t_{\text {tabel }}=1,983$, hasil ini menunjukan bahwa $t_{\text {hitung }}>t_{\text {tabel }}$ atau 5,777> 1,983, maka korelasi antara kualitas produk $\left(\mathrm{X}_{1}\right)$ dengan kepuasan pelanggan $(\mathrm{Y})$ sangat signifikan.

Adapun ringkasan hasil analisis korelasi sederhana variabel kualitas produk $\left(\mathrm{X}_{1}\right)$ dengan kepuasan pelanggan ( $Y$ ) dan uji signifikansi uji-t dapat dilihat pada tabel berikut ini.

Tabel 3. Rangkuman Hasil Analisis Korelasi dan Uji Signifikansi antara Kualitas Produk $\left(\mathrm{X}_{1}\right)$ dengan Kepuasan Pelanggan $(\mathrm{Y})$

\begin{tabular}{|c|c|ccc|}
\hline $\mathbf{N}$ & $\boldsymbol{r}_{\mathbf{x} \text {.y }}$ & $\mathbf{t}_{\text {hitung }}$ & $\begin{array}{c}\mathbf{t}_{\text {tabel }} \\
\mathbf{0 , 0 5}\end{array}$ & Kesimpulan \\
\hline 100 & $0.647^{* *}$ & 5,777 & 1,983 & $\begin{array}{c}\text { Korelasi Sangat } \\
\text { Signifikan }\end{array}$ \\
\hline
\end{tabular}

Hasil analisis korelasi tersebut menunjukan adanya hubungan positif yang sangat signifikan antara kualitas produk $\left(\mathrm{X}_{1}\right)$ dengan kepuasan pelanggan $(\mathrm{Y})$, maka dapat disimpulkan bahwa semakin baik kualitas produk akan semakin tinggi pula kepuasan pelanggan. Hasil penelitian ini juga menolak $\mathrm{H}_{0}$ yang menyatakan bahwa tidak terdapat hubungan positif antara kualitas produk dengan kepuasan pelanggan, sekaligus juga menerima $\mathrm{H}_{1}$ yang menyatakan bahwa terdapat hubungan positif antara kualitas produk dengan kepuasan pelanggan.

Berdasarkan hasil analisis regresi linear sederhana diperoleh bahwa nilai koefisien regresi $b$ adalah sebesar 0,376 dan nilai konstanta a sebesar 40,773. Dengan demikian persamaan regresi antara variabel kualitas layanan dengan kepuasan pelanggan adalah $\hat{Y}=40.773+0.376 X_{2}$.

Untuk mengetahui apakah model persamaan regresi tersebut dapat digunakan untuk menarik kesimpulan atau apakah persamaan regresi yang telah diperoleh signifikan atau tidak, dapat diketahui dengan menggunakan analisis varians (uji-F) seperti

JIMFE (Jurnal Ilmiah Manajemen Fakultas Ekonomi)

Volume 3 No. 1 Tahun 2017, Hal. 29-39 
yang diperlihatkan tabel ANOVA tersebut di bawah ini:

Tabel 4. Model ANOVA

Untuk Uji F Analisis Regresi $\hat{Y}=40.773+0.376 X_{2}$

ANOVA $^{\mathrm{a}}$

\begin{tabular}{|rl|r|r|r|r|r|}
\hline \multicolumn{2}{|l|}{ Model } & \multicolumn{1}{c|}{$\begin{array}{c}\text { Sum of } \\
\text { Squares }\end{array}$} & Df & Mean Square & $\mathrm{F}$ & \multicolumn{1}{l|}{ Sig. } \\
\hline \multirow{2}{*}{1} & Regression & 6204.761 & 1 & 7304.187 & 54.395 & $.000^{\mathrm{b}}$ \\
& Residual & 6383.603 & 99 & 56.872 & & \\
& Total & 12588.364 & 100 & & & \\
\hline
\end{tabular}

a. Dependent Variable: Kepuasan Pelanggan

a.Predictors: (Constant), Kualitas Layanan

Berdasarkan tabel di atas, maka dapat diketahui bahwa persamaan regresi $\hat{Y}=$ $40,773+0,376 X_{2}$ dapat digunakan untuk menjelaskan dan mengambil kesimpulan lebih lanjut mengenai hubungan antara kualitas layanan dengan kepuasan pelanggan, karena berdasarkan daftar nilai-nilai distribusi $F$, harga $F$ pada derajat kebebasan (dk) $\mathrm{dk}_{\text {penyebut }}=1$ dan $\mathrm{dk}_{\text {pembilang }}=99$ menghasilkan $F_{\text {tabel }}=3.94$. Dari perhitungan uji $F$ tersebut menghasilkan $F_{\text {hitung }}=54,395$. Dengan demikian sesuai kriteria pengujian signifikansi regresi, bahwa $F_{\text {hitung }}$ harus lebih besar dari $F_{\text {tabel }}$ diperoleh hasil perhitungan 54,395> 3,94. Hal ini memberi makna bahwa arah nyata pada taraf kepercayaan $95 \%$ adalah nyata.
Berdasarkan pengujian linearitas regresi diperoleh besarnya data Sig. $=0,027$ (dilihat dari nilai signifikan Deviation from Linearity yang tercantum pada tabel ANOVA). Syarat pengujian linearitas regresi adalah data Sig < taraf kesalahan $5 \%(\alpha=0,05)$. Dengan demikian karena $0,027<0,05$, maka dapat disimpulkan bahwa regresi linear diterima.

Hasil perhitungan korelasi sederhana pasangan data variabel kualitas layanan $\left(X_{2}\right)$ dengan kepuasan pelanggan (Y) menghasilkan nilai koefisien korelasi $r_{x 2 . y}$ sebesar 0,763. Dan dapat dijelaskan pada Tabel 5.

Tabel 5. Correlations untuk Data Kualitas Layanan dengan Kepuasan Pelanggan Correlations

\begin{tabular}{|ll|r|r|}
\hline & & $\begin{array}{c}\text { Kualitas } \\
\text { Layanan }\end{array}$ & $\begin{array}{r}\text { Kepuasan } \\
\text { Pelanggan }\end{array}$ \\
\hline 3Kualitas Layanan & Pearson Correlation & 1 & $.763^{* *}$ \\
& Sig. (1-tailed) & .000 \\
& $\mathrm{~N}$ & 100 & 100 \\
\hline Kepuasan Pelanggan & Pearson Correlation & $.763^{* *}$ & 1 \\
& Sig. (1-tailed) & .000 & 100 \\
& $\mathrm{~N}$ & 100 & \\
\hline
\end{tabular}

**. Correlation is significant at the 0.05 level (1-tailed). 
Angka ini menjelaskan bahwa hubungan kualitas layanan $\left(X_{2}\right)$ dengan kepuasan pelanggan $(\mathrm{Y})$ adalah positif dengan tingkat hubungan kuat.

Untuk mengetahui apakah koefisien korelasi $r_{x 2 . y}$ yang diperoleh signifikan atau tidak, dilakukan pengujian dengan menggunakan analisis uji-t. Hasil perhitungan uji-t diperoleh angka sebesar 8,352. Pada uji dua pihak dengan taraf signifikansi $\alpha=0,05$ diperoleh $t_{\text {tabel }}=1,983$, hasil ini menunjukan bahwa $t_{\text {hitung }}>t_{\text {tabel }}$ atau 8,602>1,983, maka korelasi antara kualitas layanan $\left(X_{2}\right)$ dengan kepuasan pelanggan $(Y)$ sangat signifikan.

Adapun ringkasan hasil analisis korelasi sederhana variabel kualitas layanan $\left(X_{2}\right)$ dengan kepuasan pelanggan (Y) dan uji signifikansi uji-t dapat dilihat pada tabel berikut ini.

Tabel 6. Rangkuman Hasil Analisis Korelasi dan Uji Signifikansi antara Kualitas Layanan $\left(\mathrm{X}_{2}\right)$ dengan Kepuasan Pelanggan ( $\mathrm{Y}$ )

\begin{tabular}{|ccccc|}
\hline $\mathbf{N}$ & $\boldsymbol{r}_{\mathbf{x} 2 . \boldsymbol{y}}$ & $\mathbf{t}_{\text {hitung }}$ & $\begin{array}{c}\mathbf{t}_{\text {tabel }} \\
\mathbf{0 , 0 5}\end{array}$ & Kesimpulan \\
\hline 100 & $0,763^{* *}$ & 8,602 & 1,983 & $\begin{array}{c}\text { Korelasi Sangat } \\
\text { Signifikan }\end{array}$ \\
\hline
\end{tabular}

** sangat signifikan ( $t_{\text {hitung }}>t_{\text {tabel }}$ ) $\alpha=0,05$

Hasil analisis korelasi tersebut menunjukan adanya hubungan positif yang sangat signifikan antara kualitas layanan $\left(X_{2}\right)$ dengan kepuasan pelanggan (Y), maka dapat disimpulkan bahwa semakin baik kualitas layanan akan semakin tinggi pula kepuasan pelanggan. Hasil penelitian ini juga menolak $\mathrm{H}_{0}$ yang menyatakan bahwa tidak terdapat hubungan positif antara kualitas layanan dengan kepuasan pelanggan, sekaligus juga menerima $\mathrm{H}_{1}$ yang menyatakan bahwa terdapat hubungan positif antara kualitas layanan dengan kepuasan pelanggan.

Hipotesis ketiga yang diajukan adalah terdapat hubungan positif antara kualitas produk dan kualitas layanan secara bersamasama dengan kepuasan pelanggan. Dengan kata lain bisa dikatakan bahwa semakin baik kualitas produk dan kualitas layanan, maka akan semakin tinggi kepuasan pelanggan tersebut, begitu juga sebaliknya jika kualitas produk dan kualitas layanan rendah, maka akan bertambah rendah pula kepuasan pelanggan tersebut.

Berdasarkan hasil analisis regresi linear ganda antara pasangan data kualitas produk $\left(X_{1}\right)$ dan kualitas layanan $\left(X_{2}\right)$ secara bersamasama dengan kepuasan pelanggan $(\mathrm{Y})$, diperoleh bahwa nilai koefisien regresi $b_{1}$ adalah sebesar 0,428 dan $b_{2}$ sebesar 0,236 dengan nilai konstanta a sebesar 22,612. Dengan demikian persamaan regresi ganda antara variabel kualitas produk dan kualitas layanan dengan kepuasan pelanggan adalah $\hat{Y}=22,612+0,428 X_{1}+0,236 X_{2}$.

Untuk mengetahui apakah model persamaan regresi tersebut dapat digunakan untuk menarik kesimpulan atau apakah persamaan regresi yang telah diperoleh signifikan atau tidak, dapat diketahui dengan menggunakan analisis varians (uji-F) seperti yang diperlihatkan tabel ANOVA tersebut di bawah ini: 
Tabel 7. Model ANOVA

Untuk Uji F Analisis Regresi $\hat{Y}=22,612+0,428 X_{1}+0,236 X_{2}$ ANOVA $^{a}$

\begin{tabular}{|rl|r|r|r|r|r|}
\hline Model & & \multicolumn{1}{c|}{$\begin{array}{c}\text { Sum of } \\
\text { Squares }\end{array}$} & Df & Mean Square & \multicolumn{1}{c|}{ F } & Sig. \\
\hline \multirow{2}{*}{1} & Regression & 8220.145 & 1 & 7854.132 & 152.918 & $.000^{\mathrm{b}}$ \\
& Residual & 4368.219 & 99 & 48.613 & & \\
& Total & 12588.364 & 100 & & \\
& Regression & 9241.106 & 2 & 4012.487 & 137.096 & $.000^{\mathrm{c}}$ \\
& Residual & 3347.258 & 98 & 44721 & & \\
\hline
\end{tabular}

a. Dependent Variable: Kepuasan Pelanggan

b. Predictors: (Constant), Kualitas Produk, Kualitas Layanan

Berdasarkan tabel di atas, maka dapat diketahui bahwa persamaan regresi $\hat{Y}=$ $22,612+0,428 \mathrm{X}_{1}+0,236 \mathrm{X}_{2}$ dapat digunakan untuk menjelaskan dan mengambil kesimpulan lebih lanjut mengenai hubungan antara kualitas produk dan kualitas layanan dengan kepuasan pelanggan, karena berdasarkan daftar nilai-nilai distribusi $F$ harga $\mathrm{F}$ pada derajat kebebasan ( $\mathrm{dk}$ ) $\mathrm{dk}_{\text {penyebut }}$ $=2$ dan $\mathrm{dk}_{\text {pembilang }}=98$ menghasilkan $\mathrm{F}_{\text {tabel }}=$ 3,09 Dari perhitungan uji $F$ tersebut menghasilkan $F_{\text {hitung }}=137,096$. Dengan demikian sesuai kriteria pengujian signifikansi regresi, bahwa $F_{\text {hitung }}$ harus lebih besar dari $F_{\text {tabel diperoleh hasil perhitungan }}$ $137,096>3,09$. Hal ini memberi makna bahwa arah nyata pada taraf kepercayaan $95 \%$ adalah nyata.

Hasil perhitungan korelasi ganda pasangan data antara variabel kualitas produk $\left(\mathrm{X}_{1}\right)$ dan kualitas layanan $\left(\mathrm{X}_{2}\right)$ dengan kepuasan pelanggan $(Y)$ menghasilkan nilai koefisien korelasi $R_{x 1 . x 2 . y}$ sebesar 0,740 dan dapat dijelaskan pada Tabel 8.

Tabel 8. Model Summary Untuk Data Regresi

Hipotesis 3

Model Summary

\begin{tabular}{|l|r|r|r|r|}
\hline Model & R & R Square & \multicolumn{1}{c|}{$\begin{array}{c}\text { Adjusted R } \\
\text { Square }\end{array}$} & $\begin{array}{c}\text { Std. Error of } \\
\text { the Estimate }\end{array}$ \\
\hline 1 & $.532^{\mathrm{a}}$ & .452 & .478 & 8.178 \\
2 & $.740^{\mathrm{b}}$ & .420 & .431 & 7.910 \\
\hline
\end{tabular}

a. Predictors: (Constant), Kualitas Produk

b. Predictors: (Constant), Kualitas Produk, Kualitas Layanan

Angka ini menjelaskan bahwa hubungan antara variabel kualitas produk $\left(X_{1}\right)$ dan variabel kualitas layanan $\left(X_{2}\right)$ dengan kepuasan pelanggan $(\mathrm{Y})$ adalah positif dengan tingkat hubungan sangat kuat.
Untuk mengetahui apakah koefisien korelasi $R_{x 1 . x 2 . y}$ yang diperoleh signifikan atau tidak, dilakukan pengujian dengan menggunakan $p$ value Sig. Berdasarkan hasil perhitungan uji signifikan diperoleh nilai $p$ 
value Sig sebesar $0,000<0,05$. Hal ini menunjukkan penerimaan $\mathrm{H}_{1}$, sehingga dapat disimpulkan korelasi $X_{1}$ dan $X_{2}$ secara bersama-sama dengan $Y$ signifikan.

Koefisien determinasi merupakan harga kuadrat dari koefisien korelasi. Hal ini untuk mengukur derajat hubungan variabel $X_{1}$ dan $X_{2}$ secara bersama-sama dengan variabel $Y$. Koefisien determinasi ini ditulis $R_{x 1 . x 2 . Y}$, yaitu $(0,740)^{2}=0,547$. Hal ini berarti konstribusi variabel kualitas produk $\left(\mathrm{X}_{1}\right)$ dan kualitas layanan $\left(\mathrm{X}_{2}\right)$ secara bersama-sama terhadap variabel kepuasan pelanggan $(\mathrm{Y})$ sebesar $54,7 \%$. Dengan kata lain variabel kualitas produk $\left(X_{1}\right)$ dan kualitas layanan $\left(X_{2}\right)$ secara bersama-sama menentukan hasil variabel kepuasan pelanggan $(\mathrm{Y})$.

Adapun ringkasan hasil analisis korelasi ganda antara variabel kualitas produk $\left(\mathrm{X}_{1}\right)$ dan variabel kualitas layanan $\left(X_{2}\right)$ dengan kepuasan pelanggan $(\mathrm{Y})$ dan uji signifikansi uji- $t$ dapat dilihat pada tabel berikut ini.

Tabel 9. Rangkuman Hasil Analisis Korelasi Ganda dan Uji Signifikansi antara Kualitas Produk $\left(\mathrm{X}_{1}\right)$ dan Kualitas Layanan $\left(\mathrm{X}_{2}\right)$ secara Bersama-sama dengan Kepuasan Pelanggan ( $\mathrm{Y}$ )

\begin{tabular}{|ccccc|}
\hline $\mathbf{N}$ & $\boldsymbol{R}_{\boldsymbol{x 1 . x 2 . y}}$ & $\mathbf{F}_{\text {hitung }}$ & $\begin{array}{c}\mathbf{F}_{\text {tabel }} \\
\mathbf{0 , 0 5}\end{array}$ & Kesimpulan \\
\hline 100 & $0.740 * *$ & $137.096^{* *}$ & 3.09 & $\begin{array}{c}\text { Korelasi Sangat } \\
\text { Signifikan }\end{array}$ \\
\hline
\end{tabular}

** sangat signifikan $\left(\mathrm{F}_{\text {hitung }}>\mathrm{F}_{\text {tabel }}\right) \alpha=0,05$

Hasil analisis korelasi ganda tersebut menunjukan adanya hubungan positif yang sangat signifikan antara variabel kualitas produk $\left(\mathrm{X}_{1}\right)$ dan variabel kualitas layanan $\left(\mathrm{X}_{2}\right)$ dengan kepuasan pelanggan $(Y)$, maka dapat disimpulkan bahwa semakin baik kualitas produk dan kualitas layanan akan semakin tinggi pula kepuasan pelanggan Adza Catering.

Hasil penelitian ini juga menolak $\mathrm{H}_{0}$ yang menyatakan bahwa tidak terdapat hubungan antara kualitas layanan dan kualitas layanan secara bersama-sama dengan kepuasan pelanggan, sekaligus juga menerima $\mathrm{H}_{1}$ yang menyatakan bahwa terdapat hubungan positif antara kualitas layanan dan kualitas layanan secara bersamasama dengan kepuasan pelanggan.

\section{SIMPULAN}

Berdasarkan hasil penelitian dan pembahasan mengenai hubungan antara kualitas produk dan kualitas layanan dengan kepuasan pelanggan yang telah dilakukan pada 100 pelanggan Adza Catering, maka dapat disimpulkan: 1) Terdapat hubungan positif yang sangat signifikan antara kualitas produk dan kepuasan pelanggan dengan koefisien korelasi $\left(r_{x 1 . y}\right)$ sebesar 0,647 pada tingkat hubungan kuat, dan didukung dengan persamaan regresi linear sederhana $\hat{Y}=$ $56,220+0,419 X_{1}$. Nilai koefisien determinasi $\left(r_{x 1 . y^{2}}\right)$ sebesar 0,4186 menujukan kontribusi atau sumbangan kualitas produk terhadap kepuasan pelanggan sebesar 41,86 \%. Dengan demikian kepuasan pelanggan dapat ditingkatkan melalui peningkatan kualitas produk. 2) Terdapat hubungan positif yang sangat signifikan antara kualitas layanan dan kepuasan pelanggan dengan koefisien korelasi $\left(r_{x 1 . y}\right)$ sebesar 0,763 pada tingkat hubungan kuat, dan didukung dengan persamaan regresi linear sederhana $\hat{Y}=$ $40,773+0,376 X_{2}$. Nilai koefisien determinasi $\left(r_{x 1 . y^{2}}\right)$ sebesar 0,5821 menujukan kontribusi atau sumbangan kualitas layanan terhadap kepuasan pelanggan sebesar 58,21 \%. Dengan demikian kepuasan pelanggan dapat ditingkatkan melalui peningkatan kualitas layanan. 3) Terdapat hubungan positif yang signifikan antara kualitas produk dan kualitas layanan secara bersama-sama dengan 
kepuasan pelanggan, dengan koefisien korelasi $\left(R_{x 1 \_2 y}\right)$ sebesar 0,740 pada tingkat hubungan kuat, dan didukung dengan persamaan regresi linear berganda $\hat{Y}=22,612$ $+0,428 X_{1}+0,236 X_{2}$. Nilai koefisien determinasi $\left(R_{x 1 \times 2 y}\right)$ sebesar 0,5476 menunjukkan kontribusi atau sumbangan kualitas produk dan motivasi kerja kualitas layanan secara bersama-sama terhadap kepuasan pelanggan sebesar 54,76 \%. Dengan demikian kepuasan pelanggan dapat ditingkatkan melalui peningkatan kualitas produk dan kualitas layanan secara bersamasama.

\section{DAFTAR PUSTAKA}

Abraham Bagaskara. 2014. Pengaruh Kualitas Produk, Harga, dan Citra Merek terhadap Keputusan Pembelian Sepeda Motor Honda Vario di Semarang. FEB Universitas Dipenogoro. hppt//eprint.undip.ac.id/42886/I/BAGAS KARA.pdf. Diakses pada tanggal $26 \mathrm{Mei}$ 2017.

Alma, Buchari. 2004. Manajemen Pemasaran dan Pemasaran Jasa. Bandung: Alfabeta.

Bagaskara, AM. 2014. Pengaruh Kualitas Produk, Harga dan Citra Merek terhadap terhadap Keputusan pembelian Sepeda Motor Honda Vario di Semarang Skripsi Universitas Diponogoro. Semarang.

Gerson, Richard F. 2004. Maesuring Consumer Satisfaction, diterjemahkan oleh Hesti Widyaningrum, Mengukur Kepuasan Pelanggan, Jakarta : PPM.

Ginting, Hartimbul Nembah 2011. Manajemen Pemasaran. Cetakan I. Bandung: Yrama Widia hal. 129.

Hamdani., Rambat. Lupiyoadi. 2001. Manajemen Pemasaran Jasa. Jakarta : Salemba empat.

Manajemen Pemasaran Jasa. Jakarta : Salemba empat

Hasan Ali. 2009. Marketing. Yogyakarta : MedPress.
Irawan. Handi 2007. 10 prinsip - prinsip kepuasan pelanggan.

Jasfar Farida.2005. Manajemen Jasa Pendekatan Terpadu Cetakan 1. Bogor Ghalia Indonesia.

Kotler, P. 2000. Marketing Management. New Jersey : Pearson Education.

---------. 2002. Manajemen Pemasaran, edisi millennium. Jakarta: Prehallindo.

----------. 2003. Marketing Management. New Jersey : Prantice Hall.

-------. 2005. Manajemen Pemasaran, Jilid 1 dan 2 Jakrta PT. indeks Kelompok Gramedia.

--------. 2008. Manajemen Pemasaran, edisi 4. Jakarta : Prehallindo.

Kotler, P., Keller KL. 2013. Manajemen Pemasaran, diterjemahkan oleh Bob Sabran, edisi ke-13, jilid 1. Jakarta : Penerbit Erlangga.

Kotler, Philip, Kevin Lane. 2013. Manajemen Pemasaran, edisi 13 Jilid 2. Jakarta: Prehallindo.

Lopiyoadi R. 2013. Manajemen Pemasaran Jasa (Berbasis Kompetensi) edisi ketiga. Jakarta: Salemba Empat.

Lovelock, Christoper., Wirtz Jochen, Mussry Jacky. 2010. Pemasaran Jasa. Manusia Teknologi, Strategi. Jakarta: Erlangga.

Lovelock C., Wirtz J. 2011. Pemasaran Jasa, Manusia, Teknologi, Strategi, diterjemahkan oleh Jacky Mussry. Jakarta: Erlangga.

Mohaltra Naresh K. 2005. Riset Pemasaran: Pendekatan terapan, Ed.4, jilid 1, Alih Bahasa Soleh Rusyadi Maryam, Jakarta: Indeks.

Peter J, Paul, Olson Jerry C. 2014. Consumer Behavior and Marketing Strategy, ninth edition, diterjemahkan oleh Dian Tantri Dwiandani, New York: Mc Graw-Hill Irwin and Salemba Empat.

Rangkuti, Freddy. 2008. Tehnik Mengukur \&Strategi Meningkatkan Kepuasan Pelanggan. Jakart : Gremidia Pustaka Utama. 
Sugiyono. 2010. Metode Penelitin Kuantitatif Kualitatif dan $R \& D$. Bandung: Alfabeta, CV.

Supardi. 2013. Aplikasi Statistika dalam Penelitian, Konsep Statistika yang Lebih Komprehensif. Jakarta: Change Publication.

Tai, Jacky dan Chew, Wilson. 2012. Brand Management. Jakarta : PT. Indeks.

Tandjung, Jenu Widjaja. 2004. Marketing Management: Pendekatan Pada NilaiNilai Pelanggan. Edisi Kedua. Cetakan Kedua. Bayumedia Publishing. Malang.
Tjiptono. 2007. Pemasaran Jasa. Malang. Edisi pertama, Cetakan ketiga Bayumedia Malang. Publishing.

Tjiptono, Fandy. 2006. Prinsip-prinsip Total Quality Service (TQS). Yogyakarta Penerbit ANDI.

2008. Strategi Pemasaran, Edisi ketiga. Yogyakarta Penerbit ANDI.

Zeithmal A., Varlerie, Bitner J Mary, and Gremler D. Dwayne. 2013. Services Marketing: Integrating Costumer Focus Across The Firm, Sixth Edition. Boston : Irwin McGraw-Hill Inc. 